\title{
Relation of Reproductive and Economic Functions to the Selection of Long-Term Contraception in Women of Fertile Couples in Belukur Makmur Village, Rundeng Sub-District, Subulussalam City
}

\author{
$\underline{\text { Irma Yuspita Sari Siahaan }}{ }^{1}$, Heru Santosa ${ }^{2}$, Sri Rahayu Sanusi ${ }^{2}$ \\ ${ }^{1}$ Master Student in Faculty of Public Health, Universitas Sumatera Utara, Medan, Indonesia \\ ${ }^{2}$ Lecturer in Faculty of Public Health, Universitas Sumatera Utara, Medan, Indonesia \\ Email: irma_yuspita@yahoo.co.id
}

\begin{abstract}
:
One of the population problems faced by the Indonesian people today is a large population and high maternal mortality rates. One way to suppress this growth rate is that the achievement of long-term contraceptive use must reach $65 \%$ and the role of family members in motivating the selection of contraceptives is needed. The study aimed to analyze the relationship of reproductive function and family economy with the selection of long-term contraception in women of childbearing age in Belukur Makmur Village, Rundeng Sub-District, Subulussalam Municipality. This type of research is analytical research with a cross sectional approach. The study was conducted in Belukur Makmur Village, Rundeng Sub-District, Subulussalam City, with a sample of 123 people using contraception, data collection was done by interview using a questionnaire. Data were analyzed using the chi square test. The results showed that there was a relationship between reproductive function $(p=0.014)$ and economic function $(p=0.006)$ with the selection of long-term contraception in women of childbearing age in Belukur Makmur Village, Rundeng District, Subulussalam City. Recommended to the medical workers to improve education, socialization and motivating couples of childbearing age to choose a long-term contraceptive devices through a family approach.
\end{abstract}

Keywords:

reproductive function; economic function; long-term contraception; fertile age couples

\section{Introduction}

Indonesia's population growth from year to year increase. The population problem is one of the problems encountered in the national development in Indonesia. Large population without adequate quality, will be borne by the government. During the period 2000-2010 Indonesia experienced a population increase of $1.49 \%$ per year (Sitta, 2015).

The World Population Data Sheet in 2013 said that Indonesia was the fifth country with the highest population estimate in the world at 249 million. Among ASEAN countries, Indonesia continues to be the country with the most population far above nine other countries with a total fertility rate of 2.6 where Indonesia is still above the average of ASEAN countries' Total Fertility Rate, which is 2.4 (Pusdatin, 2014).

Not only in Indonesia which has a large population, Uganda is also one of the most populated countries in the world and this is largely due to high fertility rates. Based on this problem Nakrijja et al (2018) concluded that the importance of increasing access and utilization of contraceptive users, and respondents suggested that modern contraception should be provided free of charge and extended to the household level through the ease of reaching access to family planning services. 
Family planning programs as one of the government policies in the field of population have high implications for health development, therefore family planning programs have a strategic position in an effort to control the rate of population growth. However, in reality there are still many couples of childbearing ages who are not yet participants in family planning (Dewi, 2014).

Indonesia Demographic Health Survey in 2012 showed that contraception is the widely used syringes $(31.9 \%)$, the pill (13.6\%), IUD (3.9\%), MOW (3.2\%), condoms (1.8\%), and MOP $(0.2 \%)$. It can be seen that the percentage of participants in long-term contraceptive methods is still relatively low, which means that the achievement of program targets and the reality in the field is still wide apart.

Not only in Indonesia, the World is ready to adapt sustainable development goals (SDG) and call for universal access to family planning services to ensure a healthy and prosperous life. But according to Aslam, et al, 2016 some developing countries such as Pakistan showed a declining fertility rate slowing down, the prevalence rate of contraceptive use at this time was $35 \%$, the need for family planning that was not fulfilled $20 \%$. In the upcoming sustainable development discourse the use of family planning methods is still important to improve welfare among Pakistani citizens.

Many factors that influence fertile couples do not become participants in this program include poor quality family planning services, limited contraception, delivery of counseling and communication, information, and education that has not been well implemented, cultural barriers, groups of women who do not want children again but do not use contraceptives and hard core groups, namely groups of women who do not want to use contraception both at this time and in the future (Dewi, 2014).

Research conducted by Ontiriet al, (2019), in Kenya concluded that low long-term contraceptive use in women of childbearing age was influenced by socio-demographics including education and religion, another obstacle was due to lack of human resources, lack of long-term contraceptive service provider skills, lack of contraceptive counseling and lack of involvement of men in family planning programs.

Families have a role in motivating in handling health problems. The choice of contraception is a health problem and the family has the possibility to be influenced and influence members. According to Hajasonet al, (2013) most discussions on family planning occur between couples. Almost all couples $(96 \%)$ said they first discussed this before seeking advice from others such as parents, friends and neighbors. And they recognize that parents are involved in family planning and planning decisions at different levels depending on the problem. The husband's role is lacking while the influence of others is greater than the influence of family members themselves shows the existence of problems in family functions (Sitta, 2015).

Based on the results of the preliminary preliminary study, in the working area of Rundeng Community Health Center, Rundeng Sub-District, Subulussalam Municipality in 2016, there were only $51.0 \%$ of active PUS participants, about 1,090 active participants, of which as many as 65 couples of childbearing age and those who did not use long-term contraceptive methods were 1,025. The data that I obtained from the field survey of 70 residents in Belukur Makmur Village, Rundeng Subdistrict, 62 people had more than 5 children, and 8 others had fewer than 5 children, they still believed that with a large number of children there would be a lot of sustenance, even if the mother is married at a young age, the work of the majority of housewives 
and education that is the highest is high school, and does not want to use contraception by reason of being afraid of side effects and several other reasons which are prohibited by the husband.

From the above problems, the researchers were interested in conducting research on the relationship of reproductive function and family economy with the selection of long-term contraceptives in women of reproductive age in Belukur Makmur Village, Rundeng Sub-District, Subulussalam City, 2018.

\section{Research Method}

This research is an analytic research with cross sectional approach. The study was conducted in Belukur Makmur Village, Rundeng District, Subulussalam City. The population in the study was all women of childbearing age aged 15-49 years who used contraceptives that were registered and domiciled in Belukur Makmur Village, Rundeng Sub-District, Subulussalam City, amounting to 123 people.

\section{Discussion}

\subsection{Results}

The results of the study can be seen in the following table:

Table 1. Frequency Distribution of Respondents Based on Reproductive and Economic Functions in Belukur Makmur Village, Rundeng District, Subulussalam City

\begin{tabular}{lcc}
\hline \multicolumn{1}{c}{ Family Function } & $\mathbf{n}$ & $\mathbf{\%}$ \\
\hline Reproduction & & \\
Well & 53 & 43,1 \\
Not Good & 70 & 56,9 \\
Economic & & \\
Well & 47 & 38,2 \\
Not Good & 76 & 61,8 \\
\hline
\end{tabular}

Table 1. Shows that of 123 respondents, the majority of respondents had poor reproductive function as many as 70 respondents $(56.9 \%)$ and the economic function of the majority was not as good as 76 respondents $(61.8 \%)$

Table 2. Frequency Distribution of Respondents Based on the Selection of Long-Term Contraception Devices in Belukur Makmur Village, Rundeng Sub-District, Subulussalam City

\begin{tabular}{lcc}
\hline Long-term contraception & $\mathbf{n}$ & $\mathbf{0}$ \\
\hline Use & 34 & $72,4 \%$ \\
Not Use & 89 & $27,6 \%$
\end{tabular}

Table 2. Shows that from 123 respondents the majority of respondents did not use longterm contraception as many as 89 respondents $(72.4 \%)$.

Table 3. Relationship between Reproductive Functions and the Selection of Long-Term Contraceptive Devices in Belukur Makmur Village, Rundeng District, Subulussalam City

\begin{tabular}{ccccc} 
Reproduction & \multicolumn{3}{l}{ Selection of Contraception } & $p$ \\
\cline { 2 - 5 } Functions & \multicolumn{2}{c}{ No } & \multicolumn{2}{c}{ Yes } \\
\cline { 2 - 5 } & $\mathrm{n}$ & $\%$ & $\mathrm{n}$ & $\%$ \\
\hline
\end{tabular}




\begin{tabular}{llllll} 
Not supportive & 57 & 81,4 & 13 & 18,6 & 0,014 \\
Supportive & 32 & 60,4 & 21 & 39,6 & \\
\hline
\end{tabular}

Table 3. shows that there is a relationship of reproductive function with the selection of long-term contraceptives in women of childbearing age in Belukur Makmur Village, Rundeng Sub-District, Subulussalam City because based on Chi square test results obtained $p=0.014$, this means $\mathrm{p}<0.05$ so Ho rejected. This means that there is a connection with the reproductive function of long-term contraceptive choice.

Table 4. Relationship of Economic Functions to the Selection of Long-Term Contraceptive Devices in Belukur Makmur Village, Rundeng District, Subulussalam City

\begin{tabular}{lccccc}
\hline \multirow{2}{*}{$\begin{array}{l}\text { Economic } \\
\text { Functions }\end{array}$} & \multicolumn{4}{c}{ Selection of Contraception } & $p$ \\
\cline { 2 - 5 } & \multicolumn{3}{c}{ No } & \multicolumn{3}{c}{ Yes } & \\
\cline { 2 - 5 } & $\mathrm{n}$ & $\%$ & $\mathrm{n}$ & $\%$ & \\
\hline Not supportive & 62 & 81,6 & 14 & 18,4 & 0,006 \\
Supportive & 27 & 57,4 & 20 & 42,6 & \\
\hline
\end{tabular}

Table 4. shows that there is a relationship of economic function with the selection of long-term contraceptives in women of childbearing age in Belukur Makmur Village, Rundeng Sub-District, Subulussalam Municipality because based on the Chi square test results obtained $\mathrm{p}$ $=0.006$ means that $\mathrm{p}<0.05$ so Ho rejected. This means that there is a connections economic function with a long-term contraceptive choice.

\subsection{Discussion}

\section{a. Relationship between Reproductive Functions and Long-Term Contraceptive Device Selection in Belukur Makmur Village, Rundeng Sub-District, Subulussalam City}

The family planning program is not only an effort to realize a quality family through promotion, protection, and assistance in realizing reproductive rights, but also for the provision of services, arrangements and support needed to form an ideal marriage age family, regulating the number, distance and ideal age giving birth.

The results of this study indicate that there is a relationship between reproductive function and the selection of long-term contraception in women of reproductive age in Belukur Makmur Village, Rundeng Sub-District, Subulussalam City, 2018. Contraceptive use can be influenced by sociodemographic factors (age, education, occupation, parity, number of desires for possession and status of women), environmental factors (family, community, officers), program factors (knowledge of family planning, previous experience of contraception) and facilities (availability of drugs or contraceptives, service personnel, services and costs (Fitrianingsih, 2016).

Sociodemographic factors can cause the use of long-term contraceptive methods, especially among women who have ever married in Indonesia, which is still low. There are still many women using contraception irrationally (not according to the age of the mother and the number of children desired). Many couples still use non-long-term contraception but don't want to have more children or want to postpone pregnancy for more than 2 years. This phenomenon is an inefficient matter so it needs to be studied further (BKKBN, 2011).

One of the causes that affect contraceptive choice is aged. Age affects the number of children owned and the desire to have children. The older the person the more wise in choosing a contraceptive. Women younger than 30 years are likely to not use a long-term contraceptive methods (Fitrianingsih, 2016). 
According to Setiasih's research, (2016) respondents' knowledge is very influential in the decision-making process to receive an innovation, when their knowledge and insights are good then there will be awareness to choose contraceptives to be used including freedom of choice, compatibility, effective choice or not, comfort and safety.

Yusuf's research in Fitrianingsih (2016) shows a 7.5-times higher chance of choosing nonlong-term contraception owned by couples of childbearing age who have less than three children compared to fertile couples who have more than three children. Primipara's mother (first child) is generally a young mother who does not have experience in choosing contraceptives compared to multipara mothers to choose contraception because of previous experience (Notoatmodjo, 2010). The choice of contraceptive methods is generally difficult for young and primipara mothers (first child) compared to multiparous mothers, most of whom have experience in contraceptive selection. A woman will have experience and knowledge of contraception based on the number of children she has (Fienalia, 2012).

Another research result that is in line with this research is that research conducted by Purwoko also states that when choosing contraception couples of childbearing age will be influenced by the number of children they have. Couples of childbearing age who have a small number of living children tend to use low-effectiveness short-term contraceptives, whereas in couples with a large number of children there is a tendency to use long-term contraceptive methods with high effectiveness. Couples who have children have a lot more likely to initiate contraception compared with couples who have fewer children. Families will begin to pay attention to the number of children because the number of children will be borne by the head of the family in fulfilling the material needs and maintaining the health of the reproductive system because the more often the birth of maternal health will be more vulnerable (Wiknojosastro, 2005).

\section{b. Relation of Economic Functions to the Selection of Long-Term Contraceptive Devices in Belukur Makmur Village, Rundeng District, Subulussalam City}

The results of this study indicate that there is a relationship between economic functions and the selection of long-term contraceptives in women in Belukur Makmur Village, Rundeng Sub-District, Subulussalam Municipality, 2018. This is supported by research (Lontaan et al., 2014) which shows a relationship between economic status and the choice of contraception. The results of research conducted by Rosmadewi (2015) also stated that there was a relationship between economic status and the use of long-term contraceptives in East Lampung.

This research is also in line with the research of Nita (2018) which states that the higher a person's economic status, the more influential the choice and use of contraceptives, especially the use of IUD contraception. Economic status also plays an important role because it is closely related to the ability to buy contraceptives used primarily on IUD contraception.

Based on research Unumei et al, (2015) showed that the socio-economic status of women is positively associated with the use of modern contraceptives. Although Nigeria is faced with a situation of high maternal mortality, but consistently found that women with higher socioeconomic status were more likely to use modern contraception to delay, limit and regulate labor.

One of the factors associated with the selection of contraceptives is economic factors. Usually contraceptive users pay more attention to their own daily budget limitations. The high and low economic status of the community influences the choice of contraception because the 
economic level of the community is closely related to the ability to buy contraceptives that will be used, for example families with sufficient income will be better able to participate in family planning programs than poor families. family planning programs are not a basic need.

Aslamet al, (2016) states that from the results of studies conducted in Pakistan there were socio-economic imbalances in the use of poorer and less educated female contraceptive methods in terms of the use of contraceptive methods. Fienalia (2012) states that one of the factors that influence contraceptive use is socioeconomic status, the higher a person's economic status, the easier it is to use contraception. The use of contraception requires a number of costs to obtain and use contraception in addition to the costs for contraception. Effective users of contraception reduce uncertainty about when to give birth to children and provide an opportunity to use time and energy in the economic role of the family. The cost of obtaining contraceptives is related to the socio-economic level of family income. To meet the needs of using contraception, the family will adjust in choosing the cost of contraception according to their level of ability. The amount of costs other than being closely related to the economic capacity of a family, also relates to the type of source or place to obtain contraception, one of which is injection contraception.

Another research result that is in line with this research is a study conducted by Komsari which states that there is a relationship between economic status and the choice of long-term contraception, decision making in choosing contraception is influenced by the social and economic sphere. In choosing basic or primary and secondary needs of families with good economic status, it will be easier to set aside costs for the use of contraceptives compared to families with low economic status because they are more concerned about satisfying results. While those with lower incomes think more of the urgent needs and assume that hormonal contraceptives are easier to reach than long-term contraceptives.

\section{Conclusion}

From the results of this study it can be concluded that there is a correlation between the reproductive function and family economy with the selection of long-term contraceptives in women of childbearing age in Belukur Makmur Village, Rundeng Sub-District Subulussalam City in 2018. It is suggested to improve the health personnel education, socialization and motivating couples of childbearing age to choose a long-term contraceptive devices through a family approach.

\section{References}

Aslam, Syeda Kanwal, et al. (2016). Socio-Economic Disparitis In Use Of Family Planning Methods Among Pakistani Women: Findings From Pakistan Demographic And Health Surveys. Journal of Plos One vol. 11. Accessed July 22, 2019

Alemayehu, Mussie, Belachew Tefera, Tizta Tilahun. (2012). Factors Associated with Utilization of Long Acting and Permanent Contraceptive Methods among Married Women of Reproductive Age in MekelleTown, Tigray Region, North Ethiopia. BMC Pregnancy and Childbirth, Vol. 12 (6): 1-9.

BKKBN. (2011). Further Analysis 2011. Factors Affecting the Use of MKJP in Six Indonesian Regions. Jakarta: Center for KB Research and Development and National Planning Family in 2011.

Dewi, Putri Hariyani Chandra, Notobroto, Hari Basuki. (2014). Low Participation of Users of Long-Term Contraception Methods in Fertile Couples in Tebalo Manyar Gresik Polindes, Biometrics and Population E-Journal Vol. 3 No. 1 Accessed March 31, 2018. 
Ehsanpour, Soheila, MSc, Maedeh Mohammadifard, Nafise Sadat Nekouyi, MSc. (2010). A Comparative Study On Attitude of Contraceptive Methods Users Towards Common Contraceptive Methods. Iran Journal Of Nursing And Midwifery Research. Accessed May 21,2018

Fienalia, RA. (2012). Factors Associated with the Use of Long-Term Contraceptive Methods. FKM UI Journal, Vol.7 (1).

Hajason JZ, Pina K, Raveloharisimisy JL. (2013). The influence of Family Dynamics On Contraceptive Use in Madagascar and The Ensuing Impact On Family Well-Being. Measure Evaluation PRH is Funded by the U.S. Agency For International Development (USAID) Carolina Population Center University North Carolina At Chapel Hill

Komsari, Asep Supyan, Titing Hartiningsih. 2012. The relationship between family income and the use of contraceptive methods in couples of childbearing age in Lengkong, Garawangi District, Kuningan Regency. Journal of Health Sciences Vol. 1 No 1

Lontaan, Anita, Kusmiyati, Robin Dompas. 2014. Factors Associated with Fertile Couples Contraception Selection in Damau Health Center, Talaud Regency. Julnal Scientific Midwives, Vol. 2 (1): 27-32.

Lakew, Y., Reda, A.A., Tamena, H., Benedict, S., Deribe, K. 2013. Modern Geographical Variation and Factors of Influence Contraceptive Use among Married Women in Ethiopia: Evidence from a National Population Based Survey. Reproductive Health, Vol. 10 (52): 2-10.

Nakirijja, Deborah Sarah and Mark Ivan Kayiso. 2018. Socio-Economic Determinants Fo Access To And Utilization Of Contraception Among Rural Women In Uganda. Health Science Journal. Vol. 12 No. 6 Accessed July 22, 2018

Nita, Isnaini Avia, Farid Agushybana, Yudhy Dharmawan. 2018. Economic social relations of family planning acceptors and the presence or absence of role models with IUD users. Public health journal (e-journal) Vol 6.

Ontiri, susa, et al. 2019. Long-Acting Reversible Contraception Uptake and Associated Factors Among Women of Reproductive Age In Rural Kenya. International Journal of Environmental Research and Public Health. Accessed July 22, 2019

Rosmadewi. (2015). Relationship between Knowledge and Economic Level with the Use of Contraception in the Health Center Area of Sekampung, East Lampung Regency. Sai Wawai Metro Health Journal, Vol. 8 (1): 19-24.

Sitta, Alfi Nurmas. (2015). Relationship between Family Function and Selection of IUD and Non IUD Contraception devices at KB.E-Journal acceptors of Muhammadiyah University of Surakarta. Accessed March 31, 2018.

Unumeri, Godwin, Salisu Ishaku, Babatunde Ahonsi, and Ayodeji Oginni. (2015). Contraceptive use and its socio-economic determinants among these north-east and north-west regions of Nigeria: acomparative analysis. African population studies. Vol. 29 no 2. Accessed July 22, 2019. 